University of Nebraska - Lincoln

DigitalCommons@University of Nebraska - Lincoln

Publications from USDA-ARS / UNL Faculty

U.S. Department of Agriculture: Agricultural

Research Service, Lincoln, Nebraska

$11-21-2018$

\title{
Registration of 'Matterhorn' Hard White Waxy Winter Wheat
}

\author{
Robert Graybosch \\ University of Nebraska - Lincoln, rgraybosch@gmail.com \\ P. Stephen Baenziger \\ USDA-ARS-PA Center for Grain and Animal Health Research, pbaenziger1@unl.edu \\ Dipak Santra \\ University of Nebraska-Lincoln, dsantra2@unl.edu \\ Teshome Regassa \\ University of Nebraska-Lincoln \\ Yue Jin \\ University of Minnesota, Saint Paul
}

See next page for additional authors

Follow this and additional works at: https://digitalcommons.unl.edu/usdaarsfacpub

Graybosch, Robert; Baenziger, P. Stephen; Santra, Dipak; Regassa, Teshome; Jin, Yue; Kolmer, James; Bai, Guihua; Amand, Paul St.; Chen, Richard; and Seabourn, Bradford, "Registration of 'Matterhorn' Hard White Waxy Winter Wheat" (2018). Publications from USDA-ARS / UNL Faculty. 2152.

https://digitalcommons.unl.edu/usdaarsfacpub/2152

This Article is brought to you for free and open access by the U.S. Department of Agriculture: Agricultural Research Service, Lincoln, Nebraska at DigitalCommons@University of Nebraska - Lincoln. It has been accepted for inclusion in Publications from USDA-ARS / UNL Faculty by an authorized administrator of DigitalCommons@University of Nebraska - Lincoln. 


\section{Authors}

Robert Graybosch, P. Stephen Baenziger, Dipak Santra, Teshome Regassa, Yue Jin, James Kolmer, Guihua Bai, Paul St. Amand, Richard Chen, and Bradford Seabourn 


\section{Registration of 'Matterhorn' Hard White Waxy Winter Wheat}

Robert A. Graybosch,* P. Stephen Baenziger, Dipak Santra, Teshome Regassa, Yue Jin, James Kolmer, Guihua Bai, Paul St. Amand, Richard Chen, and Bradford Seabourn

Abstract

'Matterhorn' (Reg. No. CV-1151, PI 687896) hard white winter waxy wheat (Triticum aestivum L.) was developed cooperatively by the USDA-ARS and the Nebraska Agricultural Experiment Station and released in 2018. Matterhorn, a sibling of the hard red waxy cultivar Mattern, has white grain color and waxy (amylose-free) endosperm starch. It was released primarily for its unique end-use quality attributes and for grain yield competitiveness with currently grown Nebraskaadapted cultivars. The waxy starch is conditioned by the presence of three naturally occurring mutations that eliminate production of the enzyme granule-bound starch synthase. Granule-bound starch synthase synthesizes amylose in typical wheats and other cereal crops. Matterhorn (tested as NX04Y2107W) was selected from the heterogeneous red/ white-seeded experimental line NX04Y2107 derived from the cross NW98S061/99Y1442.
This document is a U.S. government work and is not subject to copyright in the United States.

Copyright @ Crop Science Society of America. All rights reserved.

Journal of Plant Registrations 13:207-211 (2019)

doi:10.3198/jpr2018.09.0057crc

Received 7 Sept. 2018.

Accepted 21 Nov. 2018.

Registration by CSSA.

5585 Guilford Rd., Madison, WI 53711 USA

*Corresponding author (RGraybosch@gmail.com)
$\mathrm{W}$ AXY WHEATS (Triticum aestivum L.), carrying null alleles at the three $W x$ loci, produce endosperm starch free of amylose (Nakamura et al., 1993, 1995; Slade et al., 2005). The resultant waxy starch, consisting of nearly $100 \%$ amylopectin, imparts radically different functional properties compared with wild-type starches (Graybosch, 1998; Akashi et al., 2000; Hatta et al., 2000) and can be used to develop novel whole grain products (Wilson et al., 2011), as a more efficient substrate for ethanol production (Zhao et al., 2009), and can provide unique functional properties to modified food starches (Hansen et al., 2010; Graybosch and Hansen, 2016). To date, only two waxy wheat cultivars, 'Waxy-Pen' (Morris and King, 2007) adapted to the Pacific Northwest, and the hard red waxy 'Mattern' (Graybosch et al., 2014), adapted to the Great Plains, have been released in the United States.

Market classes of wheat are largely based on endosperm texture (grain hardness), grain and flour protein concentrations, and grain color (Carson and Edwards, 2009). The Great Plains of North America now produces two types of winter wheat, hard red and hard white. The red color in the grain is a result of condensed tannins or phlobaphenes, present in the seed coat. White wheats lack condensed tannins. White wheats have some potential advantages over red wheats, including wider application in non-pasta noodles and steamed wheat products, and the production of higher extraction flours (Taylor et al., 2005). The lack of condensed tannins imparts a slightly sweeter, less bitter taste to whole grain products. Whole grain products from white wheats can be significantly brighter in color, with greater appeal to consumers, than those from red wheats (Ambalamaatil et al., 2002). To fill potential demand from commercial entities for a hard white waxy wheat adapted to the Great Plains, the USDA-ARS, in cooperation with the University of Nebraska, developed and released the hard white waxy winter wheat 'Matterhorn' (Reg. No. CV-1151, PI 687896).
R.A. Graybosch (retired), USDA-ARS, 251 Filley Hall, Univ. of Nebraska, Lincoln, NE 60583; Y. Jin and J. Kolmer, USDA-ARS, 1551 Lindig St., Univ. of Minnesota, Saint Paul, MN 55108; G. Bai, P. St. Amand, R. Chen, and B. Seabourn, USDA-ARS-PA Center for Grain and Animal Health Research, 1515 College Ave., Manhattan, KS 66502; P.S. Baenziger, D. Santra, and T. Regassa, Dep. of Agronomy and Horticulture, Room 202 Keim Hall, Univ. of Nebraska-Lincoln, Lincoln, NE 68583.

Abbreviations: NRPN, Northern Regional Performance Nursery. 


\section{Methods}

\section{Selection, Seed Purification, and Increase}

Matterhorn, tested experimentally as NX04Y2107W, was selected from the heterogeneous red/white-seeded experimental line NX04Y2107 derived from the cross NW98S061/99Y1442. NW98S061 is a hard white winter wheat breeding line developed by USDA-ARS at Lincoln, NE, with the pedigree 'Jagger' (PI 593688)/'Nekota' (PI 584997). 99 Y1442 is a waxy experimental line, also developed by USDA-ARS, Lincoln, with the pedigree 'BaiHuo'/'Kanto107'(PI 631445)//'Ike'(PI 574488)/3/96MD7413-10. 96MD7413-10 is a partial waxy breeding line developed by USDA-ARS, with the pedigree NE90616/Ike. White and red seed of NX04Y2107 were separated by mechanical sorting using a Satake ScanMaster IE 200 Automated Seed Sorter housed at the Seed Science Center, Iowa State University. Red-seeded segregates of NX04Y2107 were used to develop the cultivar Mattern (Graybosch et al., 2014). White-seeded progeny were bulked to form NX04Y2107W. In 2012, spikes (heads) were obtained from a field planting of NX04Y2107W grown near Mead, NE. Heads were individually threshed with identity maintained and seed screened for grain color and the presence of waxy endosperm. One hundred white-seeded waxy-endosperm head selections were used to seed single-plant-progeny rows at Yuma, AZ. After harvest, seed of each row was retested for grain color and endosperm characteristics. All waxy/white-seeded samples were composited to form the breeding line NX04Y2107W, which was increased via a bulk planting at Yuma in 2014.

\section{Evaluation and Statistical Analysis}

Grain yield and additional agronomic traits of Matterhorn (as NX04Y2107W) were evaluated in the 2014 USDA-ARS coordinated Northern Regional Performance Nursery (NRPN; USDA, 2014). Trials were planted in randomized complete block designs with three replications at 15 locations. States and provinces hosting study sites, along with number in each, were Kansas (1), Nebraska (4), South Dakota (3), Minnesota (2), Montana (2), North Dakota (1), Wyoming (1) and Alberta (1). The NRPN contains advanced experimental lines from Great Plains wheat breeding programs. Matterhorn performance is presented relative to the control cultivars 'Overland' (PI 647959), 'Wesley'(PI 605742), 'Jagalene' (PI 631376), and 'Jerry' (PI 632433), though all trial entries were used in the analysis of variance and calculation of least significant differences (LSD, $\alpha=0.05$ ) for grain yields. Grain volume weights, plant heights, and days to heading (from 1 Jan. 2014) are presented as means without statistical analysis, due to incomplete reporting from cooperators. Matterhorn (as NX04Y2107W) also was entered in the University of Nebraska Winter Wheat Variety Test (University of Nebraska, 2016) from 2014 to 2016. Matterhorn was tested at 40 location-year environments over the 3-yr period, in randomized complete block designs with six blocks per site. All entries were used in analyses of variance of grain yield, grain volume weight and plant heights, with results presented comparing Matterhorn to the control cultivars 'Freeman' (PI 667038), Overland, 'Ruth'(PI 675998), and Wesley, as well as to its sibling Mattern. Mean responses and LSD $(\alpha=0.05)$ were computed separately for each year.
Regression analysis (Eberhart and Russell, 1966) was used to evaluate grain yield stability across environments in both the NRPN and across the 40 site-year environments of the University of Nebraska trials, years 2014 to 2016. Grain yield of each entry was used as the dependent variable, and the average grain yield of all entries at each location was used as the independent variable (environmental index). The Test statement in SAS Proc Reg was used to determine if the slope of the regression equation for each entry significantly deviated from 1.0. All trial entries were used for calculations, while only those of the control cultivars noted above are presented. Regression analysis also was used to evaluate performance of Matterhorn relative to that of its sibling Mattern across the Nebraska environments. SAS version 9.4 (SAS Institute, 2013) was used for all statistical computations.

Responses to wheat pathogens, molecular marker data, and evaluation of grain quality traits were conducted as part of the 2014 NRPN (USDA, 2014). Molecular markers and procedures are described in detail in USDA (2016). Seedling responses to stem rust (caused by Puccinia graminis Pers.:Pers. f. sp. tritici Eriks. \& E. Henn.), races QFCSC, QTHJC, MCCFC, RCRSC, RKQQC, TPMK, CTTTTF, GFMNC, QCCSM, and TTKSK, and leaf rust (caused by $P$. triticina Eriks.), races TNBGJ, MCTNB, MFPSB, TBBGJ, KFBJG, MBDSD, TFBJQ, MHDSB, TCRKG, and PBLRG, were obtained using procedures established at the USDA-ARS Cereal Disease Laboratory, St. Paul, MN (USDA, 2018a). Field adult plant responses to pathogens wheat stripe rust (caused by $P$. strifformis Westend. f. sp. tritici Eriks.), leaf rust, stem rust, Wheat soilborne mosaic virus, Wheat streak mosaic virus, additional fungal and bacterial pathogens, and acid soils were provided by cooperators in the NRPN.

Tolerance to preharvest sprouting was evaluated using procedures described by Fakthongphan et al. (2016). Samples were collected from field plantings at the University of Nebraska Eastern Nebraska Research and Extension Center near Mead. Matterhorn, along with a collection of hard red and hard white winter wheat cultivars, was planted in a randomized complete block design with three replications over two harvest seasons, 2013 and 2014. Mean responses were compared via analysis of variance and computation of LSD (0.05) and reported separately for each season, due to large and significant effects of year and entry $\times$ year interactions. Grain and flour quality traits were evaluated on Matterhorn samples from the 2014 NRPN using procedures established by the USDA-ARS Hard Winter Wheat Quality Laboratory, Manhattan, KS (USDA, 2018b). Composite samples were milled from locations within three Great Plains agroecological production zones (Peterson, 1992), treated as replications and analyzed as a completely random design with mean comparisons by LSD (0.05). High molecular weight glutenin subunit composition was determined as per Blechl and Anderson (1996).

\section{Characteristics}

\section{Agronomic and Botanical Description}

Matterhorn has a white coleoptile and erect juvenile growth pattern. The foliage is blue-green with a light waxy bloom. The leaves are glabrous. The spike is tapering, narrow, midlong, and dense. The glume is short and narrow, and the glume shoulder 
is oblique. The beak is long with an acuminate tip. Kernels are white colored, hard textured, and mainly ovate in shape. Matterhorn is an awned, tan-glumed, semidwarf cultivar that contains the Rht-B1b allele. The kernel has no collar, a large brush, rounded cheeks, with a midsize germ. Endosperm starch lacks amylose and, like all waxy starches, stains reddish-brown with $\mathrm{I}_{2} \mathrm{KI}$ (Nakamura et al., 1995).

\section{Field Performance}

In 2014, Matterhorn was entered (as NX04Y2107W) in the USDA-ARS coordinated NRPN (USDA, 2014). Average grain yield (Table 1), across 15 northern Great Plains locations, was $4123 \mathrm{~kg} \mathrm{ha}^{-1}$, not significantly different from grain yields $\left(\mathrm{kg} \mathrm{ha}^{-1}\right)$ of modern check cultivars Overland (4372), Wesley (4188); Jagalene (4235), and Jerry (4275).

In the University of Nebraska Winter Wheat Variety Tests (Table 1), Matterhorn's statewide grain yield was significantly lower than the control cultivar Ruth in 2014 and 2015, significantly lower than Overland in 2014, and significantly lower than Freeman in 2016. In all other years, grain yield of Matterhorn

Table 1. Grain yield and other agronomic traits of wheat cultivar Matterhorn compared with control cultivars.

\begin{tabular}{|c|c|c|c|c|}
\hline Entry & $\begin{array}{l}\text { Grain } \\
\text { yield }\end{array}$ & $\begin{array}{c}\text { Grain volume } \\
\text { weight }\end{array}$ & $\begin{array}{l}\text { Plant } \\
\text { height }\end{array}$ & $\begin{array}{c}\text { Days to } \\
\text { heading }\end{array}$ \\
\hline & $\mathrm{kg} \mathrm{ha}^{-1}$ & $\mathrm{~kg} \mathrm{hL}^{-1}$ & $\mathrm{~cm}$ & d from 1 Jan. \\
\hline \multicolumn{5}{|c|}{ 2014, NRPN† } \\
\hline Overland & 4372 & 76.0 & 79.1 & 164 \\
\hline Wesley & 4188 & 74.2 & 70.6 & 162 \\
\hline Jagalene & 4235 & 75.1 & 77.1 & 164 \\
\hline Jerry & 4275 & 74.6 & 86.6 & 167 \\
\hline Matterhorn & 4123 & 72.9 & 78.1 & 161 \\
\hline $\operatorname{LSD}(0.05)$ & 383 & & & \\
\hline \multicolumn{5}{|c|}{ 2014, NE State } \\
\hline Freeman & 3871 & 74.7 & 71.3 & \\
\hline Mattern & 3752 & 73.4 & 78.5 & \\
\hline Matterhorn & 3614 & 74.2 & 75.0 & \\
\hline Overland & 3970 & 75.7 & 76.6 & \\
\hline Ruth & 4115 & 75.6 & 76.2 & \\
\hline Wesley & 3679 & 74.1 & 70.6 & \\
\hline LSD & 278 & 0.9 & 3.2 & \\
\hline \multicolumn{5}{|c|}{ 2015, NE State } \\
\hline Freeman & 3324 & 67.1 & 86.4 & \\
\hline Mattern & 2880 & 65.5 & 81.0 & \\
\hline Matterhorn & 3022 & 65.5 & 78.9 & \\
\hline Overland & 3316 & 70.1 & 78.5 & \\
\hline Ruth & 3549 & 69.5 & 78.6 & \\
\hline Wesley & 2773 & 65.2 & 68.8 & \\
\hline LSD (0.05) & 319 & 3.1 & 14.0 & \\
\hline \multicolumn{5}{|c|}{ 2016, NE State } \\
\hline Freeman & 4595 & 73.6 & 91.8 & \\
\hline Mattern & 4056 & 74.7 & 93.2 & \\
\hline Matterhorn & 4016 & 74.3 & 92.2 & \\
\hline Overland & 3530 & 75.2 & 93.7 & \\
\hline Ruth & 4246 & 76.2 & 95.0 & \\
\hline Wesley & 3598 & 73.2 & 87.0 & \\
\hline LSD (0.05) & 294 & 1.6 & 2.3 & \\
\hline
\end{tabular}

† NRPN $=$ Northern Regional Performance Nursery; NE State $=$ University of Nebraska Winter Wheat Variety Trial.

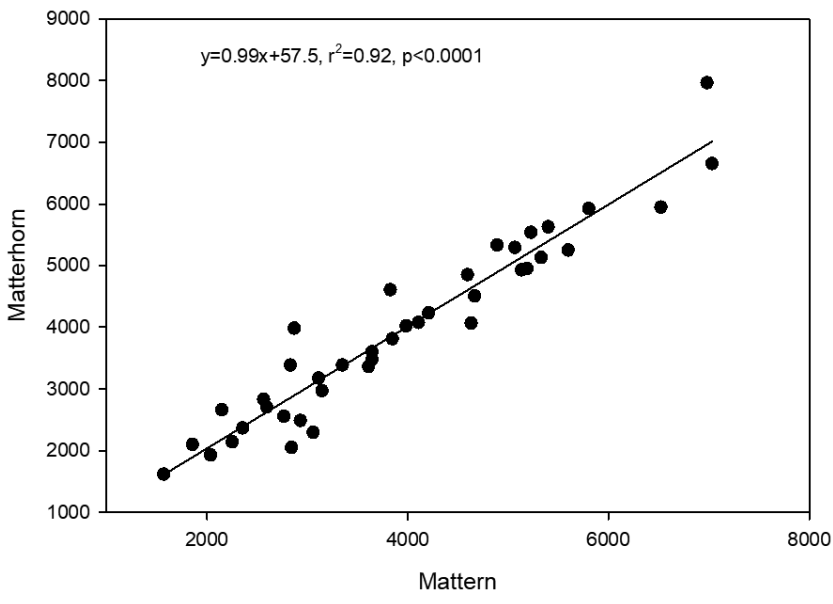

Fig. 1. Correlation of grain yields $\left(\mathrm{kg} \mathrm{ha}^{-1}\right)$, Matterhorn vs. Mattern.

did not differ from these cultivars. Matterhorn's grain yield was significantly higher than Wesley's in 2016. Across all Nebraska test environments, Matterhorn never differed significantly in grain yield from its sibling Mattern. Grain yields of these two cultivars were highly correlated (Fig. 1), indicating no grain yield penalty associated with the presence/absence of grain pigmentation.

In stability analysis, the average response of all entries is, by definition, 1.0. Any deviation in slope from this value indicates a deviation from the typical response to changing environmental conditions. The slope of Matterhorn's regression in both the NRPN and the Nebraska Winter Wheat Variety trial did not deviate from 1.0 (Table 2), nor did the slopes of any of the control cultivars, with the exception of Wesley in the Nebraska trials. This indicates Matterhorn responds to changes in environmental productivity in a similar fashion to the control cultivars.

\section{Disease Resistance}

Observations in the 2014 NRPN (USDA, 2014) and in field trials in Nebraska indicate that Matterhorn's response to stripe rust ranges from moderately susceptible to resistant, dependent on prevalent races in the test locale. Molecular marker analysis revealed the presence of the $\operatorname{Lr} 37 / \mathrm{Sr} 38 / \mathrm{Yr} 17$ complex on the 2NS:2AS chromosomal translocation from Aegilops ventricosa

Table 2. Stability analysis of wheat cultivar Matterhorn relative to control cultivars.†

\begin{tabular}{lcccc}
\hline Study $\neq$ & Entry & $\boldsymbol{b}$ value & $\boldsymbol{r}^{2}$ & $\boldsymbol{p}$ \\
\hline NRPN & Overland & 0.99 & 0.92 & 0.95 \\
& Wesley & 0.88 & 0.82 & 0.30 \\
& Jagalene & 1.04 & 0.88 & 0.71 \\
& Jerry & 0.97 & 0.71 & 0.87 \\
& Matterhorn & 0.95 & 0.83 & 0.69 \\
NE State & Freeman & 0.95 & 0.92 & 0.34 \\
& Mattern & 1.01 & 0.94 & 0.97 \\
& Matterhorn & 1.02 & 0.91 & 0.78 \\
& Overland & 0.88 & 0.86 & 0.08 \\
& Ruth & 0.96 & 0.92 & 0.34 \\
& Wesley & 1.11 & 0.96 & 0.01 \\
\hline
\end{tabular}

† Regression parameters presented: $b$ value (slope), $r^{2}=$ coefficient of determination, $p=$ probability slope ( $b$ value) equals 1.0.

$\neq$ NRPN $=$ Northern Regional Performance Nursery, NE State $=$ University of Nebraska Winter Wheat Variety Trial. 
(Zhuk.) Chennav. Matterhorn is susceptible to most prevalent races of leaf rust but is postulated to carry the seedling resistance genes $\mathrm{Lrl}$ and $\mathrm{Lrl} \mathrm{Ha}$. Seedling stem rust resistance is present to races QFCSC, QTHJC, MCCFC, RCRSC, TPMKC, and QCCSM, though Matterhorn is susceptible to stem rust race $\mathrm{Ug} 99$ and its derivatives. Matterhorn is tolerant of acid soil conditions and carries the Al4DL+ allele (Ma et al., 2005) for this trait, based on marker WMC00331. Matterhorn demonstrates field tolerance to the Wheat soilborne mosaic virus/Wheat spindle streak mosaic virus complex, bacterial streak [caused by Xanthomonas translucens pv. undulosa, (Xtu.)], and dwarf bunt (caused by Tilletia controversa Kuhn). It is susceptible to wheat curl mite (Aceria tosichella Keifer), Hessian fly [Mayetiola destructor (Say)] biotype GP, greenbug [Schizaphis graminum (Rondani)] biotype E, and Russian wheat aphid [Diuraphis noxia (Kurdjumov)] biotype 2 .

\section{End-Use Quality}

End-use quality attributes of Matterhorn, due to the presence of amylose-free (waxy) starch, differ markedly from those of wild-type wheats (Table 3). Flour yield was significantly lower than in the control cultivars, a characteristic typical of waxy wheats (Graybosch et al., 2003). Flour pasting properties, as measured by the Rapid Viscoanalyzer, also differed markedly from the controls and from typical wheats in general (Table 3).

The observed low stirring number and short pasting time are typical of waxy wheats, are independent of $\alpha$-amylase activity (Graybosch et al., 2000), and are not indicative of preharvest sprouting. Polyphenol oxidase activity is not low and is similar to the red wheat controls. Matterhorn's hardness score is typical of hard wheats and equal to that of Wesley and Jerry. Grain and flour protein concentrations, mixograph scores, bake mix time, and loaf volume of Matterhorn fall within the ranges observed for wild-type wheats (Table 3). Baked loaves of Matterhorn will collapse on cooling, another trait typical of waxy wheats. Matterhorn displayed significantly higher mixograph water absorption than all of the controls and significantly higher bake water absorption than all controls except Wesley. Preharvest sprouting tolerance of Matterhorn, using a surrogate assay (Fakthongphan et al., 2016), is intermediate, significantly greater than susceptible white wheats such as 'Arrowsmith' and 'Anton' (Table 4), statistically equal to that of its red wheat sibling Mattern, equal to known tolerant white wheats such as 'Danby', but significantly lower than the tolerant red wheat 'Camelot' and the tolerant white wheat 'Clark's Cream'. Molecular marker analyses using PHS-4A-34586_92 (USDA, 2014) indicate that Matterhorn carries a marker allele linked to preharvest sprouting tolerance on 4AL. Both Matterhorn and Mattern produce the high-molecular-weight glutenin protein subunits $2^{*}, 7+9,5+10$.

\section{Availability}

The US Department of Agriculture will not have seed for commercial distribution but will accept requests for licensing. The seed classes will be breeder, foundation, registered, and certified. Matterhorn has been submitted (application \#201800398) for US Plant Variety Protection under P. L. 10577 with the certification option. Seed of Matterhorn has been deposited into the USDA-ARS National Laboratory for Genetic Resources Preservation, where it will be available for research purposes immediately upon publication.

\section{Acknowledgments}

Matterhorn was developed with partial financial support from the Nebraska Wheat Development, Utilization, and Marketing Board. Funding for R.A. Graybosch was derived from USDA-ARS Project Number 5440-21000-031-00, Genetic Improvement of Winter Wheat for End-Use Quality and Disease Resistance. The authors wish

Table 3. Grain and flour quality attributes of Matterhorn compared to control cultivars, 2014 Northern Regional Performance Nursery (NRPN).

\begin{tabular}{|c|c|c|c|c|c|c|c|c|c|}
\hline Entry & $\begin{array}{c}\text { Grain } \\
\text { hardness }\end{array}$ & $\begin{array}{l}\text { Grain protein } \\
\text { concentration }\end{array}$ & Flour yield & Flour ash & $\begin{array}{l}\text { Flour protein } \\
\text { concentration }\end{array}$ & $\begin{array}{c}\text { Flour } \\
\text { polyphenol } \\
\text { oxidase (OD }+ \text { ) }\end{array}$ & $\begin{array}{c}\text { Flour } \\
\text { absorption }\end{array}$ & $\begin{array}{l}\text { Mixograph } \\
\text { mix time }\end{array}$ & $\begin{array}{l}\text { Mixograph } \\
\text { tolerance }\end{array}$ \\
\hline & hardness units & 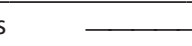 & $\mathrm{g} \mathrm{kc}$ & -1 & - & & $\mathrm{g} \mathrm{kg}^{-1}$ & $\min$ & $0-5$ \\
\hline Jagalene & 68 & 134.7 & 685 & 4.50 & 122.0 & 0.54 & 632 & 4.3 & 3.7 \\
\hline Jerry & 54 & 134.7 & 696 & 3.97 & 123.3 & 0.61 & 632 & 3.6 & 3.0 \\
\hline Kharkof & 39 & 148.7 & 653 & 4.27 & 135.0 & 0.59 & 630 & 3.5 & 3.3 \\
\hline Matterhorn & 57 & 138.0 & 588 & 4.13 & 125.0 & 0.67 & 659 & 2.5 & 1.0 \\
\hline Overland & 63 & 131.3 & 688 & 4.17 & 117.0 & 0.58 & 624 & 2.5 & 0.7 \\
\hline Wesley & 56 & 140.7 & 700 & 4.00 & 130.7 & 0.69 & 643 & 4.0 & 2.7 \\
\hline $\operatorname{LSD}(0.05)$ & 3 & 5.1 & 15 & 0.38 & 5.1 & 0.06 & 3 & 0.5 & 1.0 \\
\hline \multirow[t]{2}{*}{ Entry } & $\begin{array}{l}\text { RVA§ pasting } \\
\text { time }\end{array}$ & $\begin{array}{l}\text { RVA stirring } \\
\text { number }\end{array}$ & $\begin{array}{l}\text { RVA peak } \\
\text { viscosity }\end{array}$ & $\begin{array}{l}\text { RVA final } \\
\text { viscosity }\end{array}$ & $\begin{array}{l}\text { Bake water } \\
\text { absorption }\end{array}$ & Bake mix time & Loaf volume & & \\
\hline & $\min$ & units & units & units & $\mathrm{g} \mathrm{kg}^{-1}$ & $\min$ & $\mathrm{mL}$ & & \\
\hline Jagalene & 6.2 & 119 & 235 & 283 & 632 & 5.2 & 943 & & \\
\hline Jerry & 6.2 & 135 & 214 & 277 & 628 & 4.8 & 885 & & \\
\hline Kharkof & 6.3 & 142 & 245 & 288 & 628 & 4.7 & 987 & & \\
\hline Matterhorn & 3.4 & 71 & 102 & 24 & 651 & 4.1 & 985 & & \\
\hline Overland & 6.2 & 134 & 233 & 284 & 610 & 3.0 & 845 & & \\
\hline Wesley & 6.2 & 126 & 227 & 280 & 643 & 6.3 & 990 & & \\
\hline LSD (0.05) & 0.09 & 11 & 20 & 21.7 & 13 & 0.7 & 44 & & \\
\hline
\end{tabular}

†OD = optical density.

₹ Mixograph tolerance scored on a scale of 0 to 5 , with $0=$ no tolerance, $5=$ greatest tolerance.

$\S \mathrm{RVA}=$ Rapid Viscoanalyzer. 
Table 4. Sprouting tolerance (delta†) of Matterhorn compared to a collection of Great Plains hard red and hard white winter wheats.

\begin{tabular}{|c|c|c|c|c|}
\hline Entry & PIno. & Market class $\neq$ & 2013 & 2014 \\
\hline Arrowsmith & PI 633911 & HW & 130.7 & 79.6 \\
\hline Anton & PI 651044 & HW & 107.8 & 85.2 \\
\hline Platte & PI 596297 & HW & 126.7 & 56.3 \\
\hline Antelope & PI 633910 & HW & 132.4 & 40.9 \\
\hline Alliance & PI 573096 & HRW & 106.7 & 55.3 \\
\hline Alice & PI 644223 & HW & 111.5 & 37.4 \\
\hline NuDakota & PI 643089 & HW & 99.8 & 45.9 \\
\hline McGill & PI 659689 & HRW & 111.3 & 33.5 \\
\hline Millennium & PI 612390 & HRW & 105.7 & 24.9 \\
\hline Overland & PI 647959 & HRW & 91.5 & 34.2 \\
\hline Snowmass & PI 658597 & HW & 97.0 & 28.1 \\
\hline Pronghorn & PI 593047 & HRW & 59.9 & 59.1 \\
\hline Nuplains & PI 605741 & HW & 66.2 & 49.9 \\
\hline TAM 111 & PI 631352 & HRW & 83.3 & 25.5 \\
\hline Settler CL & PI 653833 & HRW & 79.4 & 26.3 \\
\hline Trego & PI 612576 & HW & 71.5 & 24.0 \\
\hline Danby & PI 648010 & HW & 78.6 & 24.1 \\
\hline Mattern & PI 665947 & hard red waxy & 66.1 & 30.0 \\
\hline Matterhorn & PI 687896 & hard white waxy & 60.2 & 33.5 \\
\hline Robidoux & PI 659690 & HRW & 53.1 & 32.7 \\
\hline TAM 107 & PI 495594 & HRW & 64.6 & 19.6 \\
\hline Niobrara & PI 584996 & HRW & 55.3 & 23.2 \\
\hline Wesley & PI 605742 & HRW & 44.0 & 17.9 \\
\hline Jagalene & PI 631376 & HRW & 42.8 & 17.4 \\
\hline Mace & PI 651043 & HRW & 36.7 & 22.0 \\
\hline Camelot & PI 653832 & HRW & 37.0 & 16.3 \\
\hline Clark's Cream & PI 476305 & HWW & 10.1 & 12.6 \\
\hline Mean & & & 78.9 & 35.4 \\
\hline LSD (0.05) & & & 35.0 & 12.1 \\
\hline
\end{tabular}

† Delta $=$ change in shoot and root area of seed within heads after misting treatment. Higher values = greater susceptibility to preharvest sprouting.

‡ HW = hard white; HRW = hard red winter.

to acknowledge the technical assistance of Lori Divis, Vern Hansen, Jorge Venegas, Juthamas Fakthongphan, Gregory Dorn, Mitchell Montgomery, and all cooperators participating in the NRPN and University of Nebraska wheat testing programs. Any opinions, findings, conclusions, or recommendations expressed in this publication are those of the authors and do not necessarily reflect the view of the USDA.

\section{References}

Akashi, H., S. Endo, K. Hatta, K. Hayakawa, T. Hoshino, S. Ishigami, S. Ito, T. Nakamura, S. Tago, K. Tanaka, M. Yamamori, and R. Yoshikawa. 2000. Flour blends for breads, cakes, or noodles, and foods prepared from the flour blends. US Patent 6042867. Date issued: 28 March.

Ambalamaatil, S., O.M. Lukow, D.W. Hatcher, J.E. Dexter, L.J. Malcolmson, and B.M. Watts. 2002. Milling and quality evaluation of Canadian hard white spring wheats. Cereal Foods World 47:319-327.

Blechl, A.E., and O.D. Anderson. 1996. Expression of a novel high-molecular-weight glutenin subunit gene in transgenic wheat. Nat. Biotechnol. 14:875-879. doi:10.1038/nbt0796-875

Carson, G.R., and N.M. Edwards. 2009. Criteria of wheat and flour quality. In: K. Khan and P.R. Shewry, editors, Wheat: Chemistry and technology. AACC International, St. Paul, MN. p. 97-118. doi:10.1094/9781891127557.004
Eberhart, S.T., and W.A. Russell. 1966. Stability parameters for comparing varieties. Crop Sci. 6:36-40. doi:10.2135/cropsci1966.0011183X00060 $0010011 x$

Fakthongphan, J., R.A. Graybosch, and P.S. Baenziger. 2016. Combining ability for tolerance to pre-harvest sprouting in common wheat (Triticum aestivum L.). Crop Sci. 56:1025-1035. doi:10.2135/cropsci2015.08.0490

Graybosch, R.A. 1998. Waxy wheats: Origin, properties and prospects. Trends Food Sci. Technol. 9:135-142. doi:10.1016/S0924-2244(98)00034-X

Graybosch, R.A., P.S. Baenziger, D. Santra, T. Regassa, Y. Jin, J. Kolmer, S. Wegulo, G. Bai, P. St. Amand, X. Chen, B.W. Seabourn, F.E. Dowell, R.L. Bowden, and D.S. Marshall. 2014. Release of 'Mattern' waxy (amylosefree) winter wheat. J. Plant Reg. 8:43-48. doi:10.3198/jpr2013.08.0045crc

Graybosch, R.A., G. Guo, and D.R. Shelton. 2000. Aberrant falling numbers of waxy wheats independent of alpha-amylase activity. Cereal Chem. 77:13. doi:10.1094/CCHEM.2000.77.1.1

Graybosch, R.A., and L.E. Hansen. 2016. Functionality of chemically modified waxy, partial waxy and wild-type starches from common wheat. Starke 68:496-504. doi:10.1002/star.201500241

Graybosch, R.A., E. Souza, W. Berzonsky, P.S. Baenziger, and O.K. Chung. 2003. Functional properties of waxy wheat flours: Genotypic and environmental effects. J. Cereal Sci. 38:69-76. doi:10.1016/S0733-5210(02)00139$\mathrm{X}$

Hansen, L.E., D.S. Jackson, R.L. Wehling, and R.A. Graybosch. 2010. Functionality of chemically modified wild-type, partial waxy and waxy starches from tetraploid wheats. J. Cereal Sci. 51:409-414. doi:10.1016/j. jcs.2010.02.010

Hatta, K., K. Hayakawa, T. Hoshino, S. Ishigami, S. Ito, Y. Kawamura, H. Miyamura, M. Mizukami, Y. Murayama, T. Nakamura, S. Tago, Y. Tanaka, K. Tanaka, M. Yamamori, and R. Yoshikawa. 2000. Flour blends for deep fried foods, steamed Chinese manju, dough sheets, okonomi-yaki, and takoyaki. US Patent 6139894. Date issued: 1 October.

Ma, H.X., G.H. Bai, B.F. Carver, and L.L. Zhou. 2005. Molecular mapping of a quantitative trait locus for aluminum tolerance in wheat cultivar Atlas 66. Theor. Appl. Genet. 112:51-57. doi:10.1007/s00122-005-0101-5

Morris, C.F., and G.E. King. 2007. Registration of 'Waxy-Pen' soft white spring waxy wheat. J. Plant Reg. 1:23-24. doi:10.3198/jpr2006.08.0551crc

Nakamura, T., M. Yamamori, H. Hirano, and S. Hidaka. 1993. Identification of three Wx proteins in wheat. Biochem. Genet. 31:75-86. doi:10.1007/ BF02399821

Nakamura, T., M. Yamamori, H. Hirano, S. Hidaka, and T. Nagamine. 1995. Production of waxy (amylose-free) wheats. Mol. Gen. Genet. 248:253-259. doi:10.1007/BF02191591

Peterson, C.J. 1992. Similarities among test sites based on cultivar performance in the hard red winter wheat region. Crop Sci. 32:907-912. doi:10.2135/ cropsci1992.0011183X003200040014x

SAS Institute. 2013. The SAS system for Windows. Release 9.4. SAS Inst., Cary, NC.

Slade, A.J., S.I. Fuerstenberg, D. Loeffler, M.N. Steine, and D. Facciotti. 2005. A reverse genetic, nontransgenic approach to wheat crop improvement by TILLING. Nat. Biotechnol. 23:75-81. doi:10.1038/nbt1043

Taylor, M.R., G.W. Brester, and M.A. Boland. 2005. Hard white wheat and Gold Medal flour: General Mills' contracting program. Rev. Agric. Econ. 27:117-129.

University of Nebraska. 2016. Winter wheat variety test results. University of Nebraska-Lincoln. https://cropwatch.unl.edu/winter-wheat-variety-testresults (accessed 31 Oct. 2018).

USDA. 2014. Hard winter wheat regional nursery program. USDA. https:// www.ars.usda.gov/plains-area/lincoln-ne/wheat-sorghum-and-forageresearch/docs/hard-winter-wheat-regional-nursery-program/research/ (accessed 31 Oct. 2018).

USDA. 2016. USDA central small grains genotyping laboratory. USDA. http://www.hwwgenotyping.ksu.edu/ (accessed 31 Oct. 2018).

USDA. 2018a. Cereal disease laboratory. USDA. https://www.ars.usda.gov/ midwest-area/stpaul/cereal-disease-lab/ (accessed 31 Oct. 2018).

USDA. 2018b. Hard winter wheat quality laboratory. USDA. https://www. ars.usda.gov/plains-area/mhk/cgahr/gqsru/ (accessed 31 Oct. 2018).

Wilson, L.A., J.W. Colyn, G. Lai, and C. Morris. 2011. Waxy wheat products and processes for producing same. US Patent 7935376. Date issued: 3 May.

Zhao, R., X. Wu, B.W. Seabourn, S. Bean, L. Guan, Y. Shi, J.D. Wilson, R. Madl, and D. Wang. 2009. Comparison of waxy vs. nonwaxy wheats in fuel ethanol fermentation. Cereal Chem. 86:145-156. doi:10.1094/CCHEM86-2-0145 